\title{
OUR AFFAIR WITH A RUFFED GROUSE
}

CLARENCE FORSBERG, 407 Albert Avenue, Saskatoon, Saskatchewan S7N 1 G2.

In the evening of 1 September 1978, while my wife, Ann, and I, along with visitors from Ontario, were sitting in front of our mobile home at Moon Lake, south of Saskatoon, a male Ruffed Grouse walked out of the bush and circled us at a distance of about 15 feet. At Ann's suggestion, one of our visitors tossed out Choke Cherries, each one successively closer to his chair. The grouse continued to walk about in a majestic manner, but somehow never missed noting the location of each berry and eventually picked it up. This continued until the beautiful bird was within 3 feet of our visitor and there were no more berries. He then dangled his fingers. The grouse, while showing no apparent attention and continuing to move about, suddenly flew to grasp one of the fingers in its beak for an instant and returned to the 3-foot position. After one repeat performance our visitor chose not to risk his fingers again. The elegant bird continued to walk around us as suggestions were made for a suitable name. Pierre was nominated and favorably accepted. By this time it was getting dark and Pierre walked back into the bush.

The next evening, Ann and I drove to Moon Lake and immediately went down to the trees 60 feet below and 200 yards from our mobile home to pick berries. After picking for awhile we noticed Pierre within 10 feet of us. Twice, during about 2 hours of picking, he apparently tried to fly up on Ann's shoulder when her back was turned to him. When it was too dark to pick, we walked back to our mobile home with Pierre walking and running about 10 yards behind us, never choosing to fly even up the very steep portions of the path. Again, when it was quite dark, he walked away into the bush.

Several days later, I went to Moon Lake to jack up one of the outside corners of the anteroom. When I had removed the skirt from one side of it, I noticed Pierre at my side. Being afraid he might go in under the mobile home, I tried to scare him away. But nothing doing - that brave bird stood his ground and it was not until I picked up an old raincoat and swung it around that I got him to move off several feet. I gave up trying to keep him away and he showed no interest in getting under the mobile home. Whenever he was within a few feet, I was careful not to make a sudden move in his direction in case he might fly at me. During the morning he walked away into the bush many times but never stayed away more than a few minutes at a time.

Over the period 1 September to 25 November we were at Moon Lake 11 times. On all occasions, except one, Pierre walked out of the bush to visit us. The exception was one late evening in September when it was very windy, cool and cloudy. We would call his name and whistle on our arrival and he would walk out of the bush over one of his two paths within 5 minutes. He always arrived by walking. Only on one occasion did he leave by flying. He exploded into 
flight about 10 feet from us with a whir of wings for two seconds which propelled him sailing at high speed for 150 yards where he disappeared among the tall poplars below us. We were a bit stunned and duly impressed by the power of this unusual bird.

Later, on another visit, Pierre followed us on our walk through the woods below, flying silently from the ground or from trees. Around the mobile home he would sometimes fly quietly to view us from the roof or from the top of our car. The open door of the anteroom was a favourite perch to which he hung tenaciously when the wind blew the door or when we wished to close and lock it before leaving. Once, from his perch on the door, he flew down to deliver a good bump on the back of my head. At no time did we offer Pierre anything but a few berries picked at Moon Lake, his natural food, and this only on three occasions. In late October, when large dry leaves from our northwest poplar were lying on the ground, we were pleased to see him eat a couple of these, stem and all, with apparent relish.

Our visit from Pierre on 5 November was the most memorable. Some of our first snow remained on the wet ground in the bushes and yet Pierre appeared as usual within 5 minutes. We stood around for a long time while he periodically walked back into the bush as though inviting us to follow. When it was getting dark and we thought he was not coming back any more, we walked the 75 yards out to the road, where our car was parked. We were about to drive off when Pierre hit on the windshield, slid down on the hood and stood looking in at us. After a minute he got on a sloping part of the hood and slid onto the ground. He walked through the ditch and under our yard fence. Then as we drove off he ran along inside the fence. Since the hill was a bit slippery we did not stop until we had reached the top. Thinking the fall "crazy period" for Ruffed Grouse should be over and that we might never see him again, we sat for a long time looking back, but no Pierre. We drove off a little sad but also happy with our experience with this beautiful and unforgettable bird.

As it turned out we did see Pierre again on 25 November, 6 and 20 January, and on 21 April, but he was increasingly wary. On four visits during this period he did not appear and not again after 21 April.

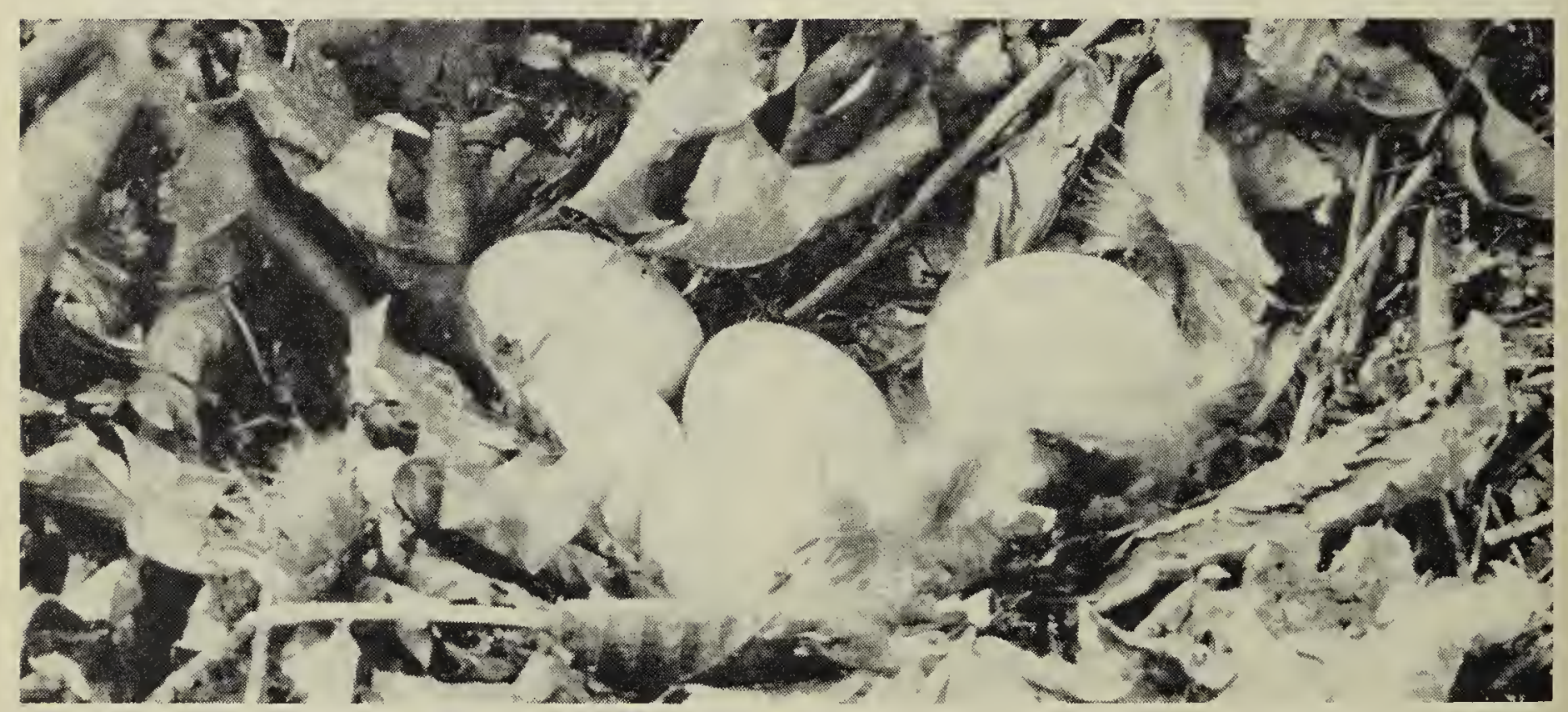

